\title{
Orthetrum chrysostigma (Burmeister, 1839): new for the Italian fauna (Odonata Libellulidae)
}

\author{
Andrea Corso ${ }^{* *}$ \& Verena Penna ${ }^{2}$ \\ ${ }^{1}$ Via Camastra 10, 96100 Siracusa, Italy \\ ${ }^{2}$ Via di Santa Maria dell'Anima 61, 00185 Roma, Italy \\ "Corresponding author, e-mail: zoologywp@gmail.it
}

\begin{abstract}
Details about the first Italian record of Orthetrum chrysostigma (Burmeister, 1839) (Odonata Libellulidae), obtained in south-western Sicily, are reported. One mature male was collected in the province of Agrigento in August 2014.
\end{abstract}

KEY WORDS Dragonflies; first record; North Africa; Sicily; Italy.

Received 11.11.2019; accepted 03.03.2020; published online 28.04.2020

\section{INTRODUCTION}

Orthetrum chrysostigma (Burmeister, 1839) is one of the most widespread and common species of Libellulidae Anisoptera in Africa, its range expanding to southern Europe and Turkey with the northern limits of distribution in Portugal and the Ebro Delta in Spain, while the eastern limit is found in southern Anatolia (Boudot et al 2009; Boudot \& Kalkman, 2015). In North Africa, it is very common in Tunisia, both in coastal areas with a high percentage of rainfall and in the oases of inner desert areas (Jödicke et al. 2000; Boudot et al., 2009; pers. obs.). The species is also well distributed in Morocco and Algeria (Jacquemin \& Boudot, 1999; Boudot et al., 2009; Boudot \& Kalkman, 2015; Corso pers. obs.). In Spain and Portugal the distribution range is rather wide with large populations (Boudot et al 2009; Boudot \& Kalkman, 2015). For the island of Malta, four records are known between 2008 and 2010 (Gauci \& Sciberras, 2010). It also appears that there may be a reproductive population on the island (Corso et al., 2012).

In Italy, there were no known records (Riservato et al., 2015).

\section{MATERIAL AND METHODS}

The area of Torre Salsa nature reserve (Agrigento, Sicily, Italy) was repeatedly visited, mainly during June to August, to observe and study Odonata. The site is of considerable interest for its environmental characteristics and the excellent state of conservation. Further, the relatively low distance from the African coasts (Tunisia), favours the discovery of rare or extra Italian species. All the sampling were carried out through identification from photographic documentation (see Aguesse, 1968; Askew, 2004; Dijkstra \& Lewington, 2006; Gagliani et al., 2017). Only in few case, some specimens were caught by using entomological nets, observed for a more in-depth study, and then left free in the field again. The specimens here reported and discussed, however, were out of the nature reserve's borders, therefore it was decided to collect and preserve them (AC legit, M. Pavesi collection, Milano, Italy).

\section{RESULTS}

In August 2013, in the brackish ponds of the nature reserve of Torre Salsa, we thought we had ob- 
served $O$. chrysostigma. However, on 26th August 2014 other interesting Orthetrum sp. were observed just outside Torre Salsa Nature Reserve. Fortunately, 4 male were collected $\left(37^{\circ} 22^{\prime} 31.48^{\prime \prime} \mathrm{N}\right.$, $\left.13^{\circ} 19^{\prime} 43.87^{\prime \prime} \mathrm{E}\right)$. On closer examination, three of these specimens were determined as $O$. coerulescens (Fabricius, 1798), showing secondary genitalia intermediate between the typic $O$. coerulerescens and the taxon O. coerulerescens anceps (Schneider, 1845) (considered a separate species, a subspecies or simply a geographical variant of $O$. coerulerescens), or closer to the latter (Mauersberger, 1994, Klingenberg, 1994, Klingenberg \& Martens, 1996) (Figs. 8, 9). Instead, 1 male was determined as a mature specimen of $O$. chrysostigma, based on its secondary genitalia morphology (Fig. 3) and the shape of the S3-S4 abdominal segments. This specimen, sent to $\mathrm{M}$. Pavesi in order to confirm its identification (now kept in his entomological collection), represent the first ever record for Italy.

The structure of the secondary genitalia was found to be the key identification character: the anterior lamina appears to be very slightly protruding (Figs. 3, 4). The similar species are the aforementioned $O$. coerulescens (chiefly "anceps"), Orthetrum nitidinerve (Sélys-Longchamps, 1841), $O$. brunneum (Fonscolombe, 1837) and O. ransonnetii (Brauer, 1865) which results not yet recorded in Europe up to date. In both sexes, O. chrysostigma shows a characteristic pattern with pale bands diagonally across the thorax, called "epaulette" (Fig. 1). These pale bands differentiates it from other similar Orthetrum species observable in Europe and North Africa (Aguesse, 1968, Askew, 2004, Dijkstra \& Lewington, 2006, Dijkstra \& Clausnitzer, 2014). However, in mature, pruinose male, chiefly in old ones, this pattern is hardly appreciable or almost completely obscured, making it resembling the other species here above reported (Fig. 2). From $O$. coerulescens it is distinguished mainly by the anterior lamina of the secondary genitalia that appears decidedly less protruding, less prominent and more convex rather than concave (Figs. 3, 4, 7-9). Moreover, $O$. coerulescens (including the slender and more delicate looking "anceps") lacks the peculiar and unique tapering at the sides of the $3 \mathrm{rd}$ and 4 th abdominal segments (S3-S4). Further, $O$. chrysostigma shows at the base of the wings (chiefly the hindwing) a small amber patch or spot, that could be more or less extensive, though some- times hardly visible (or missing in forewing). Orthetrum brunneum appear rather different, being of a paler cerulean colour, appearing bigger, "heavier", with different genitalia (smaller anterior lamina and genital lobe) (Fig. 5). Orthetrum nitidinerve might appears similar, showing pale legs, a skinny, "light" body and a similar general colour. The analysis of the genitalia again makes easy the identification but, once detected the waisted abdominal segments (S3-S4), the determination it is easy also in the field. In addition, the unique pale yellow outer costa and inner vain of the forewing of nitidinerve is another helpful difference. In an extra European context, $O$. ransonnetii is the closest species showing very similar secondary genitalia (Fig. 6). Orthetrum ransonnetii shows a more "muscular", heavier general structure, longer and thicker upper appendages (Figs. 10, 11), has a darker membranula at the base of hindwings, which are lacking the pale amber patch or spot. As with all the other similar species, the tapering, waisted abdominal segments of $O$. chrysostigma readily distinguish it from $O$. ransonnetii as well.

\section{DISCUSSION}

Further on-site surveys carried out by us in August 2015-2019, have failed to detect additional imagoes of $O$. chrysostigma. Also, other researchers have carried out observations in the same years in July-August, without being able to detect the presence of the species (M. Pavesi, S. Surdo \& C. Muscarella pers. com.). The area where we obtained this new odonata for Italy, it is of considerable relevance for the Sicilian fauna of dragonflies and damselflies, 21 species were recorded so far: Calopteryx haemorrhoidalis (Vander Linden, 1825), Lestes barbarus (Fabricius, 1798), Ischnura geneii (Vander Linden, 1820), Ceriagrion tenellum (Villers, 1789), Erythromma lindenii (Sélys, 1840), Aeshna mixta Latreille, 1805, A. affinis (Vander Linden, 1820), A. isoceles (Müller, 1767), Anax imperator Leach, 1815, An. parthenope Selys, 1839, An. ephippiger (Burmeister, 1839), Orthetrum brunneum (Fonscolombe, 1837), O. coerulescens (Fabricius, 1798), O. cancellatum (Linnaeus, 1758), Crocothemis erythraea (Brullé, 1832), Sympetrum fonscolombii (Sélys, 1840), S. meridionale (Sélys, 1841), S. striolatum (Charpentier, 1840), Trithemis annulata 
(Palisot de Beauvais, 1805), Selysiothemis nigra (Vander Linden, 1825) and Brachythemis impartita (Karsch, 1890). Our record of O. chrysostigma brings the number of Odonata species recorded in Italy to 96 (Riservato et al., 2014; Viganò et al., 2017). This make Italy, together with France (96 species as well), the European country with the richest odonate fauna, followed by Spain (88) (Viganò et al., 2017). The total species number for Europe is 144 (cf. Boudot \& Kalkman, 2015) and that for the Western Palaearctic is 201, with the latest addition of Tramea basilaris (Palisot de Beauvois, 1807) documented at Linosa (Pelagie islands, Sicily) (Viganò et al., 2017). At the current state of knowledge, it is not clear whether the record here reported is due to the presence of a small population settled in the study area (as happened on the island of Malta), or it is simply referable to occasional occurrence attributable to vagrants accidentally arrived from the Tunisian coasts (presumably in correspondence of strong scirocco or, even more, libeccio winds). In fact, the latter hypothesis is reflected by the observation of other migratory or dispersal species of odonata recently reported as new for the Italian fauna at the Pelagie islands and in Sicily: Pantala flavescens (Fabricius, 1798), Trithemis kirbyi Selys, 1891, Sympetrum sinaiticum Dumont, 1977 and Tramea basilaris (Palisot de Beauvois, 1807), the first two species being regularly recorded while the other being rare vagrants recorded only once or

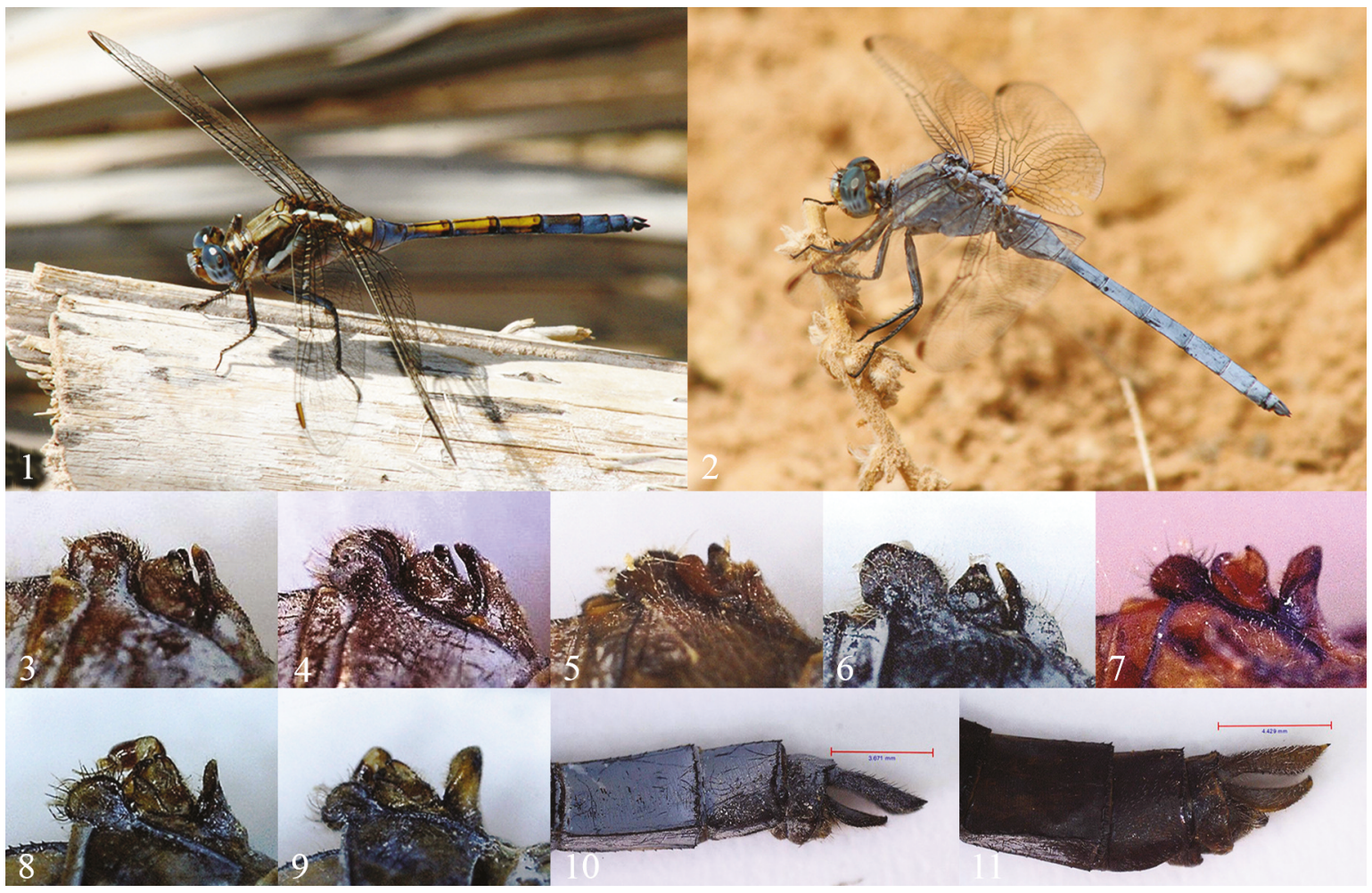

Figure 1. Young male of Orthetrum chrysostigma, 13.IV.2019, Morocco, Aoulouz, AC. Note the characteristic pale band ("epaulette") typical of this species. Figure 2. Mature male of O. chrysostigma, Morocco, Aoulouz, 13.IV.2019, AC. Note that old pruinose males may lack altogether the typical "epaulette" or barely show this pattern, making the identification harder. In older male the pale band is not visible at all. Compared to other European Orthetrum sp. note the slender abdomen, which is waisted at segments S3-S4, the pale membranula and the amber coloured small patch at the base of hindwing. Figure 3, 4. Secondary genitalia of the mature male of O. chrysostigma. Fig. 3: Torre Salsa (Agrigento, Sicily, Italy), 37²2’31.48’N, 1319'43.87’'E, 26.VIII.2014 (AC). Fig. 4: Morocco, near Aoulouz, 13.IV.2019. Figure 5. Idem, O. brunneum, Italy, Sicily, Castelvetrano, 30.VII.2011, AC. Figure 6. Idem, O. ranssonnetii, Morocco, Askaoun, Anti-Atlas, 2.III.2011, AC. Figure 7. Idem, O. cf. coerulescens ssp., Italy, Sicily, Fiume Anapo (Siracusa), 25.VII.2013, AC. Figure 8. Idem, O. cf. coerulescens (closer to "anceps"), Italia, Torre Salsa (Agrigento, Sicily), 26.VIII.2014, AC. Figure 9. Idem, O. coerulescens (intermediate?), Italy, Torre Salsa (Agrigento, Sicily), 26.VIII.2014, AC. Figure 10. Appendages of the mature male of $O$. chrysostigma, Torre Salsa (Agrigento, Sicily, Italy), 26.VIII.2014. Figure 11. Idem, O. ranssonnetii, Morocco, Askaoun, Anti-Atlas, 2.III.2011. 
twice (Corso et al., 2012, 2017; Viganò et al., 2017). It is doubtless and was indeed demonstrated by our researches, that thanks to strong south winds, and in particular weather condition, vagant species may easily reach Sicily and its surrounding islands: these may colonise in the future the area, or may simply, most probably, remains rarities. Other species should be actively searched in Sicily and its circumSicilian islands, such as Orthetrum sabina (Drury, 1770), and Ischnura saharensis Aguesse, 1958 to quote some of them, while Diplacodes lefebvrii (Rambur, 1842) was recently recorded from the island of Linosa, Pelagie Archipelago (Agrigento, Sicilian Channel) (Janni et al., 2020).

\section{ACKNOWLEDGEMENTS}

A dutiful and heartfelt thanks to our friend Maurizio Pavesi (Milano, Italy), for having confirmed the determination of the specimen sent to him and discussed here. A special thanks also to Roberto Casalini (Roma, Italy) and the staff of MCZR (Museo Civico di Zoologia di Roma) for the help with the photos of the secondary genitalia.

\section{REFERENCES}

Aguesse P., 1968. Les Odonates de l'Europe Occidentale, du Nord de l'Afrique et des Iles Atlantiques. Faune de l'Europe et du Bassin Méditerranéen. 4. Masson et Cie Editeurs, Paris, 258 pp.

Askew R.R., 2004. The Dragonflies of Europe (revised edition). Harley Books (B.H. \& Harley Ltd), Colchester, England, 291 pp.

Boudot J.-P., Kalkman V.J., Azpiliculeta Amorín M., Bogdanović T., Cordero Rivera A., Degabriele G., Dommanget J.-L., Garrigós B., Jović M., Kotarac M., Lopau W., Marinov M., Mihoković N., Riservato E., Samraoui B. \& Schneider W., 2009. Atlas of the Odonata of the Mediterranean and North Africa. Libellula, Supplement 9: 1-256.

Boudot J.-P. \& Kalkman V.J., 2015. Atlas of the European dragonflies and damselflies. KNNV Publishing, The Netherlands, 384 pp.

Corso A., Janni O., Pavesi M., Sammut M., Sciberras A. \& Viganò M., 2012. Annotated checklist of the dragonflies (Insecta Odonata) of the islands of the Sicilian Channel, including the first records of Sympetrum sinaiticum Dumont, 1977 and Pantala flavescens (Fabricius, 1798) for Italy. Biodiversity Journal, 3: 459-478.

Corso A., Viganò M., Janni O. \& Pavesi M., 2017.
Update to the status of Pantala flavescens (Fabricius, 1798) and Trithemis kirbyi Selys, 1891 for Italy and Central Mediterranean basin (Odonata Libellulidae). Biodiversity Journal, 8: 33-38.

Dijkstra K.-D.B. \& Lewington R., 2006. Field guide to the dragonflies of Britain and Europe. British Wildlife Publishing, Gillingham, 320 pp.

Dijkstra K.-D.B. \& Clausnitzer V., 2014. The Dragonflies and Damselflies of Eastern Africa: handbook for all Odonata from Sudan to Zimbabwe. Royal Museum for Central Africa 1-260.

Galliani C., Scherini R. \& Piglia A., 2017. Dragonflies and Damselflies of Europe. WBA Handbooks, 352 pp.

Gauci C. \& Sciberras A., 2010. First records of Orthetrum chrysostigma (Odonata Libellulidae) Burmeister, 1839 in the Maltese Islands. Central Mediterranean Naturalist, 5: 78-80.

Jödicke R., Arlt J., Kunz B., Lopau W. \& Seidenbusch R., 2000. The Odonata of Tunisia. International Journal of Odonatology, 3: 41-71.

Jacquemin G. \& Boudot J.-P., 1999. Les libellules (odonates) du Maroc. Société Française d'Odonatologie, Bois d'Arcy.

Janni O., Viganò M. \& Corso A., 2020. First records of Diplacodes lefebvrii (Rambur, 1842) for Sicily and additional record of Trithemis kirbyi Selys, 1891 (Odonata Libellulidae). Biodiversity Journal, 11: 65-68. https:// doi.org/10.31396/Biodiv.Jour.2020.11.1.65.68

Klingenberg K.,1994. Lassen sich Orthetrum coenilescens (Fabricius 1798) und O. anceps (Schneider 1848) auf Grund morphologischer und molecular genetischer Kriterien als zwei eindeultg voneinander verschiedene Arten ansehen (Odonata: Libellulidae)? Dipl. Arb., Univ. Braunschweig.

Klingenberg K. \& Martens A., 1996. Record of an intermediate form between Orthetrum coerulescens (Fabricius) and $O$. anceps (Schneider) in southern Spain (Anisoptera: Libellulidae). Advances Odonatology, Supplement 1: 117-121.

Mauersberger, R., 1994. Zurwirklichen Verbreitung von Orthetrum coerulescens (Fabricius) und O. ramburi $($ Selys $)=O$. anceps $($ Schneider) in Europa und die Konsequenzen für deren taxonomischen Rang (Odonata, Libellulidae). Deutsche Entomologische Zeitschrift, 41: 235-256.

Riservato E., Festi A., Fabbri R., Grieco C., Hardersen S., Laporta G., Landi F., Siesa M.E. \& Utzeri C., 2014. Odonata. Atlante delle libellule italiane - preliminare. Società Italiana per lo Studio e la Conservazione delle Libellule. Edizioni Belvedere, Latina, 224 pp.

Vigano' M., Janni O. \& Corso A., 2017. Tramea basilaris on Linosa Island, Italy: a new species for Europe and the Western Palaearctic (Odonata: Libellulidae). Odonatologica 46: 55-66. 